\title{
Effect of stunning of diagnostic 131-iodine doses on ablative doses for differentiated thyroid cancer patient's outcome
}

\author{
Khaled El-Saban ${ }^{1}$, Hiji Al-Sakhri ${ }^{2}$, Abdullah Al-Zahrani ${ }^{1}$ \\ 1. Faculty of Medicine, Taif University, Saudia Arabia. 2. Al-Hada Armed Force Hospital, Saudia Arabia. \\ Correspondence: Khaled El Saban. Address: Faculty of Medicine, Taif University, Saudia Arabia. \\ Email: kelsaban@gmail.com
}

Received: September 22, 2013 Accepted: September 29, 2013

URL: http://dx.doi.org/10.5430/jst.v3n6p11

DOI : $10.5430 /$ jst.v3n6p11

Online Published: October 18, 2013

\section{Abstract}

Background: Thyroid stunning was defined as transient reduction of thyroid tissue uptake 131I (RAI-131) ablative dose after a diagnostic 131I dose that decreases the final absorbed dose in ablative therapy.

Aim of the study: after following the proper precautions compare the response to the ablative dose given to patients with differentiated thyroid cancer with or without diagnostic radioactive iodine 131(RAI-131).

Patients and methods: One hundred patients with differentiated thyroid cancer were included and divided into two groups: Group I, ablative dose of RAI-131according to their risk stratification without diagnostic dose and Group II, patients performing diagnostic whole body scan [5mCi] followed by ablative dose.

Results: The current study have showed no significant associations between overall response in both groups and the different studied parameters except for the mean ablative dose of RAI- $131[r=0.9 ; P<0.001$ and $r=0.7, P<0.001$ in group I and group II respectively]. Correlation matrix was used in all patients revealed that overall response was highly correlated with risk stratification; cervical nodal status and RAI-131 ablative dose [ $P$ values $<0.01 ;<0.01$ and $<0.01$ respectively], while regression proved that the only predictor for response is the mean RAI-131 ablative dose.

Conclusion: Following the proper precautions prevent stunning appearance after the diagnostic dose success rate to ablation will not be affected.

\section{Key words}

Differentiated thyroid carcinoma, Ablative dose, Thyroid stunning

\section{I ntroduction}

Differentiated thyroid carcinoma (DTC) represents $1 \%$ of all malignancies, with long-term survival (a 10-year survival of more than $90 \%{ }^{[1]}$, following the available guidelines and experience of experts ${ }^{[2,6]}$.

Diagnostic RAI-131 scanning post thyroidectomy is mandatory to estimate the amount of residual tissue remaining, the tumor avidity of residual tissue, and the appropriate $131 \mathrm{I}$ dosimetry ${ }^{[7,8]}$. In some patients, imaging of thyroid tissue residue using of RAI-131 diagnostic scan may induce within few hours up to days the so-called stunning phenomenon ${ }^{[8]}$. 
The latter is considered a radiobiological suppressive phenomenon defined as a temporary suppression of iodine trapping function of the thyrocytes and thyroid cancer cells as a result of the radiation given off by the scanning or first dose of RAI-131 ${ }^{[5]}$. Concern for stunning has led some physicians to prescribe treatments of RAI-131 without prior diagnostic imaging in hopes of increasing the therapeutic effect ${ }^{[6,7]}$. There was a marked difference in the ability to detect iodine-avid tissue when a post-therapy scan is read at 7-10 days, rather than at 2-3 days ${ }^{[8]}$.

The current study aims to compare the response to the post operative ablation of patients with differentiated thyroid cancer using radioactive iodine 131(RAI-131) between two groups of patients: group I given ablative dose of RAI-131according to their risk stratification; and Group II performing diagnostic whole body scan (Dx-WBS) [5mCi] followed by ablative dose (following the required precautions to avoid stunning).

\section{Patients and Methods}

\subsection{Patients}

Inclusion criteria: The current study included 100 patients who had undergone surgery [near total thyroidectomy with cervical lymph nodes selective dissection) for well differentiated thyroid carcinoma and were referred to Nuclear Medicine unit Al-Hada Forced arm hospital, Taif Saudia Arabia for 131I ablation. None of them had received any prior radioiodine therapy.

Exclusion criteria: We excluded patients who had distant functioning organ metastases [as bone or lungs] on diagnostic or post therapy whole body scans.

The institutional review board approved our study and was made aware of the additional radiation dose. All patients consented to be subjected to the current study with full explanation of the protocol and they were informed of the radiation dose and its risks. They also consented to the use of their data for future retrospective research.

\subsection{Methods}

\subsubsection{Clinical protocol}

On presentation all patients were subjected to the following procedures: clinical history, serum thyroglobulin $(\mathrm{Tg})$ and Neck ultrasonography (U.S.).

Patients in group I (50 patients) were given an ablative dose of RAI-131 directly followed by post therapy whole body scan using axis dual head Siemens gamma camera fitted with high-energy collimators for simultaneous anterior and posterior whole body images at speed $8 \mathrm{~cm} / \mathrm{sec}$. The energy window was set at $20 \%$ centered on $364 \mathrm{keV}$ with a $256 \times 1024$ size matrix. Spot views of the head and neck using the same collimator and the same energy window as for the whole-body images were also obtained in a $128 \times 128$ matrix size with a total count of $300 \mathrm{~K}$ count and images were interpreted qualitatively by visual assessment of the size and tracer uptake intensity of the residual uptake.

Patients in group II (50 patients) were initially evaluated by the same manner as the group I but with initial diagnostic whole body scan (Dx-WBS), performed at variable periods after thyroidectomy, followed by the ablative dose. Diagnostic whole body scans were done after withdrawal of levothyroxine medication 3-4 weeks with TSH $\geq 30 \mathrm{IU} / \mathrm{mi}$ before administration of $5 \mathrm{mCi}$ of RAI-131. Seventy-two hours after oral intake of RAI-131, Dx-WBS was performed using dual-head Siemens gamma camera fitted with high energy collimators for simultaneous anterior and posterior whole-body images at speed $8 \mathrm{~cm} / \mathrm{sec}$. The energy window was set at $20 \%$ centered on $364 \mathrm{keV}$ with a $256 \times 1024$ size matrix. Spot views of the head and neck using the same collimator and the same energy window were also obtained in a $128 \times 128$ matrix size with a $20 \%$ energy window for $15 \mathrm{~min}$. The therapeutic dose was administered on the same day as or a few days after the scanning dose was read; the time elapsed between administration of the scanning dose and the therapeutic dose was 
typically 2-5 days ${ }^{[8,9]}$. Ablative doses given to patients ranged between $3700-7400 \mathrm{MBq}(30-150 \mathrm{mCi})$. All patients were instructed to follow a low iodine diet beginning 10-14 d before the initial scan, treatment, and follow-up scan.

All posttherapy scans were read at two intervals: 2 and 7-10 days after treatment. None of the patients treated had completely negative post-therapy scans. Images were interpreted by two observers blindly.

\subsubsection{Follow up and evaluation of ablation efficacy}

Follow up was done using neck ultrasound, serum TG level as well as Dx-WBS for all patients. Dx-WBS was done 6 months after initial therapy, all patients were prepared in the same way for the administration of radioiodine by withdrawal of levothyroxine medication 3- 4 weeks before administration of 3-5mCi of RAI-131.

Image interpretation was made qualitatively and our criteria for successful remnant ablation defined as: Absence of any significant RAI-131 uptake at the thyroid bed; $\mathrm{Tg}<2 \mathrm{mg}$ and negative neck sonography. Accordingly two categories were identified either complete or no response to ablation.

Risk of recurrence: Recurrence may be either local (in thyroid bed or cervical lymph node) or distant. Accordingly, risk stratification can be either low, intermediate or high risk according to the American Thyroid Association (ATA) as shown in table $1^{[10,11]}$. High risk patients were excluded from this study.

Table 1. Risk of recurrence stratification (low, intermediate or high risk) ${ }^{[10]}$



Note. High risk patients were excluded from this study.

\subsection{Statistical method}

Data were either parametric or non-parametric. Parametric data was statistically described in terms of mean + standard deviation (SD), and range. Non-parametric data was described as frequencies (number of cases) and percentages when appropriate. Comparison of parametric variables between the studied groups was done using unpaired Student $\mathrm{t}$ test. For nonparametric data, comparison was done using Chi square $\left(\chi^{2}\right)$ test. Multivariate analyses were done using two steps first correlation matrix followed by regression analysis. Test was considered significant when $\mathrm{P}$ values became less than 0.05 . 
All statistical calculations were done using computer programs SAS/STAT software (Statistical Analysis System, SAS Institute Inc.) Microsoft Windows.

\section{Results}

The current study included 100 patients, 77 females (77\%) and 23 males (23\%) referred for 131I ablation post near total thyroidectomy. Their age ranged from $22-54$ years; mean of $40.88 \pm 12.3$. The commonest histopathology was papillary thyroid carcinoma, encountered in 73 patients (73\%) while 27 patients (27\%) have follicular thyroid carcinoma. Risk assessment of the patients showed 87 (87\%) patients were intermediate risk and 13 patients (13\%) with low risk. High risk patients were excluded from this study. The analysis of histopathological data showed presence of capsular invasion in 25 (25\%) patients and vascular invasion in $8(8 \%)$ patients. Metastatic lymph node involvement was found only in 13 patients (13\%). There was no significant difference between the studied groups concerning the patient characteristics Table 2.

Table 2. Patient characteristics of the studied patients

\begin{tabular}{|c|c|c|c|c|}
\hline & $\begin{array}{l}\text { Group I } \\
\text { [no. 50] }\end{array}$ & $\boldsymbol{P}$ & $\begin{array}{l}\text { Group II } \\
\text { [no. 50] }\end{array}$ & Total \\
\hline \multicolumn{5}{|l|}{ Age } \\
\hline$<45$ years & $35[70 \%]$ & $>0.05$ & $30[60 \%]$ & $65[65 \%]$ \\
\hline$\geq 45$ years & $15[30 \%]$ & $>0.05$ & $20[40 \%]$ & $35[35 \%]$ \\
\hline Mean \pm SD [years] and & $39.4 \pm 13.1$ & $>0.05$ & $43.8 \pm 11.3$ & $40.88 \pm 12.3$ \\
\hline Range & $23-49$ & & $22-54$ & $22-54$ \\
\hline \multicolumn{5}{|l|}{ Gender } \\
\hline Males & $15[30 \%]$ & $>0.05$ & $8[16 \%]$ & $23[23 \%]$ \\
\hline Females & $35[70 \%]$ & & $42[84 \%]$ & $77[77 \%]$ \\
\hline \multicolumn{5}{|l|}{ Operation Type } \\
\hline Near Total Thyroidectomy & $50[100 \%]$ & $>0.05$ & $50[100 \%]$ & $100[100 \%]$ \\
\hline \multicolumn{5}{|l|}{ Pathological Type } \\
\hline Papillary & $38[75 \%]$ & $>0.05$ & $35[70 \%]$ & $73[73 \%]$ \\
\hline Follicular & $12[25 \%]$ & & $15[30 \%]$ & $27[27 \%]$ \\
\hline \multicolumn{5}{|l|}{ Histopathological } \\
\hline Capsular Invasion & $15[30 \%]$ & $>0.05$ & $10[20 \%]$ & $25[25 \%]$ \\
\hline Vascular Invasion & $3[6 \%]$ & $>0.05$ & $5[10 \%]$ & $8[8 \%]$ \\
\hline Lymph node deposits & $5[10 \%]$ & $>0.05$ & $8[16 \%]$ & $13[13 \%]$ \\
\hline \multicolumn{5}{|l|}{ Maximum Tumor size } \\
\hline$<1 \mathrm{~cm}$ & $5[10 \%]$ & $>0.05$ & $10[20 \%]$ & $15[15 \%]$ \\
\hline$\geq 1 \mathrm{~cm}$ & $45[90 \%]$ & $>0.05$ & $40[80 \%]$ & $85[85 \%]$ \\
\hline \multicolumn{5}{|l|}{ Risk Stratification } \\
\hline Low & $5[10 \%]$ & $>0.05$ & $8[16 \%]$ & $13[13 \%]$ \\
\hline Intermediate & $45[90 \%]$ & $>0.05$ & $42[84 \%]$ & $87[87 \%]$ \\
\hline $\begin{array}{l}\text { Post-operative Radioactive } \\
\text { I-131 Diagnostic Scan } \\
\text { [3-5 mCi] }\end{array}$ & None & 0.0001 & $\begin{array}{l}\text { All Cases } \\
100 \%\end{array}$ & $50[50 \%]$ \\
\hline \multicolumn{5}{|l|}{ Ablative Dose [mCi] } \\
\hline Mean \pm SD & $107.25 \pm 27.4$ & $>0.05$ & $116.9 \pm 28.5$ & $112.1 \pm 28$ \\
\hline Range & $30-150$ & & $30-150$ & $30-150$ \\
\hline
\end{tabular}


On follow up; there was no significant statistical difference between both groups concerning response. The study disclosed $38(76 \%)$ and $35(70 \%)$ in group I and II respectively had negative results in the Dx WBS and neck sonography; Table 3. Comparison of response in both groups in relation to ablative dose revealed no significant statistical difference for each dose subgroup Figure 1.

A

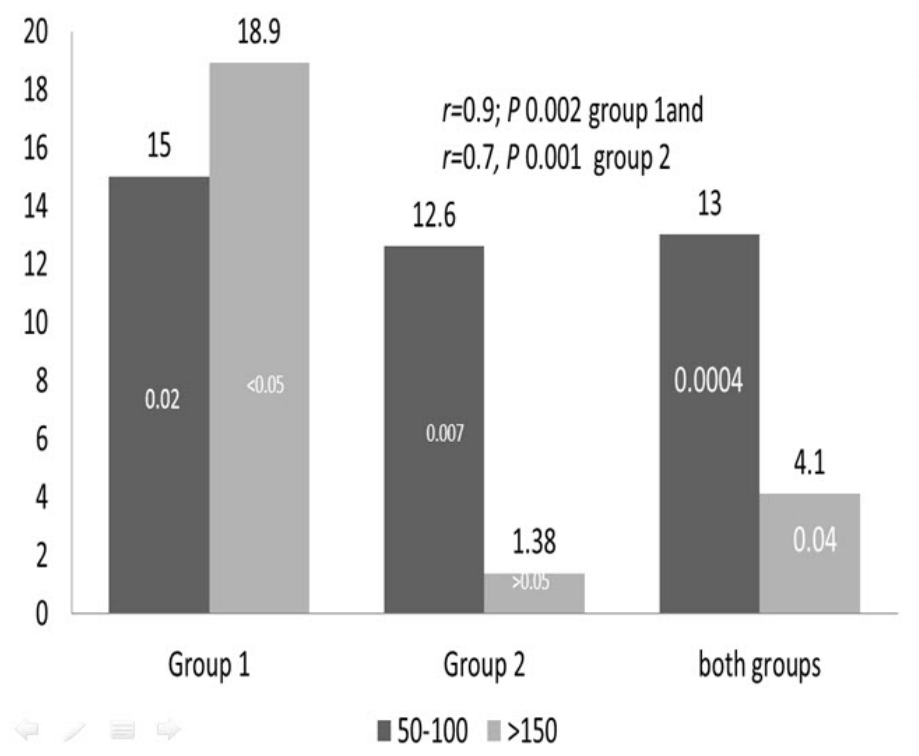

B

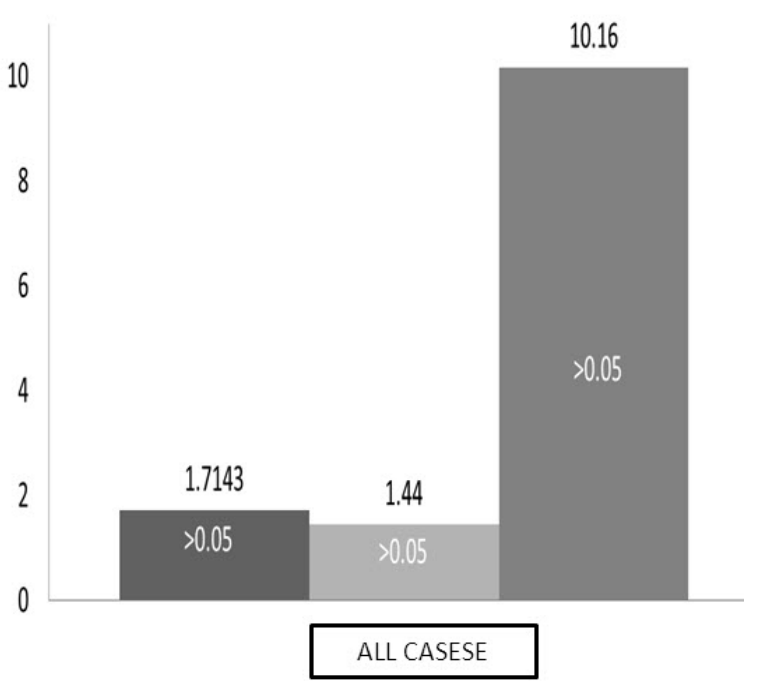

$\|<50 \backsim 50-100 \backsim 100-150$

Figure 1. Impact of ablative dose rate on the response of thyroid cancer remnant in both groups

A. Logistic regression using odd ratio of ablation doses in both groups. B. Odd Ratio of Ablation doses each in both groups.

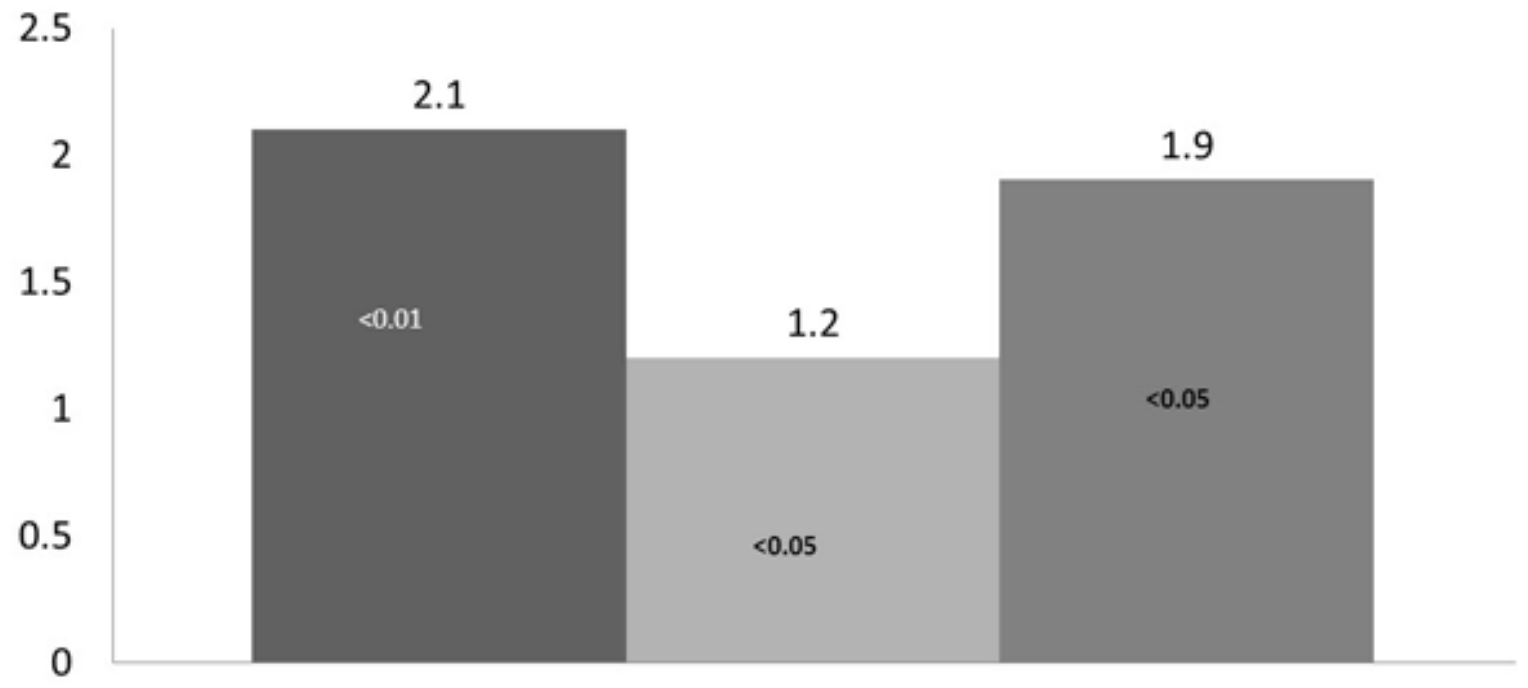

risk stratification $\quad$ LN involvement $\quad$ Ablative dose

Figure 2. Factors affecting response to radioiodine131 in Cancer thyroid 
Table 3. Response assessment in the studied groups

\begin{tabular}{|c|c|c|c|c|}
\hline Follow-up Tool & $\begin{array}{l}\text { Group I } \\
\text { [no. 50] }\end{array}$ & $\boldsymbol{P}$ & $\begin{array}{l}\text { Group II } \\
\text { [no. 50] }\end{array}$ & Total \\
\hline \multicolumn{5}{|l|}{$\begin{array}{l}\text { Radioactive I-131 Diagnostic Scan } \\
{[3-5 \mathrm{mCi}]}\end{array}$} \\
\hline Negative & $45[90 \%]$ & $>0.05$ & $42[84 \%]$ & $>0.05$ \\
\hline Positive for residue or metastasis & $5[10 \%]$ & $>0.05$ & $8[16 \%]$ & $>0.05$ \\
\hline \multicolumn{5}{|l|}{ Neck Sonography } \\
\hline Negative & $38[76 \%]$ & $>0.05$ & $35[70 \%]$ & $>0.05$ \\
\hline $\begin{array}{l}\text { Positive for residue or cervical lymph } \\
\text { nodes }\end{array}$ & $12[24 \%]$ & $>0.05$ & $15[30 \%]$ & $>0.05$ \\
\hline \multicolumn{5}{|l|}{ Thyroglobulin } \\
\hline Negative $<2$ & $40[80 \%]$ & $>0.05$ & $40[80 \%]$ & $>0.05$ \\
\hline Positive $\geq 2$ & $10[20 \%]$ & $>0.05$ & $10[20 \%]$ & $>0.05$ \\
\hline
\end{tabular}

No significant associations were elicited between overall response in both groups and the different studied parameters except for the mean dose of radioactive 131 [ $r=0.9 ; P<0.001$ and $r=0.7, P<0.001$ in group I and group II respectively and table 4]. Table 4 revealed the highly significant dependence of response on the dose in each group separate where doses below $50 \mathrm{mCi}$ showed statistically the lowest response. Fig.1a but no difference in the same dose subgroup Fig1b, where odd ratio was found insignificant in the three subgroups, $<50,50-100$ and $>100-150$ between group I and II.

Table 4. Impact of dose of ablation and presence or absence of diagnostic dose on the response

\begin{tabular}{|c|c|c|c|c|c|c|c|c|c|c|c|c|c|c|}
\hline \multirow[b]{3}{*}{$\begin{array}{l}\text { Ablation } \\
\text { dose }\end{array}$} & \multicolumn{4}{|c|}{ Group I } & \multicolumn{4}{|c|}{ Group II } & \multicolumn{4}{|c|}{ Both groups } & \multicolumn{2}{|c|}{ Total } \\
\hline & \multicolumn{2}{|c|}{ Responders } & \multicolumn{2}{|c|}{$\begin{array}{l}\text { Non- } \\
\text { responders }\end{array}$} & \multicolumn{2}{|c|}{ Responders } & \multicolumn{2}{|c|}{$\begin{array}{l}\text { Non- } \\
\text { responders }\end{array}$} & \multicolumn{2}{|c|}{ Responders } & \multicolumn{2}{|c|}{$\begin{array}{l}\text { Non- } \\
\text { responders }\end{array}$} & \multirow[b]{2}{*}{ No. } & \multirow[b]{2}{*}{$\begin{array}{l}\% \text { of } \\
\text { total }\end{array}$} \\
\hline & No. & $\begin{array}{l}\% \text { of } \\
\text { total }\end{array}$ & No. & $\begin{array}{l}\% \text { of } \\
\text { total }\end{array}$ & No. & $\begin{array}{l}\% \text { of } \\
\text { total }\end{array}$ & No. & $\begin{array}{l}\text { \%of } \\
\text { total }\end{array}$ & No. & $\begin{array}{l}\% \text { of } \\
\text { total }\end{array}$ & No. & $\begin{array}{l}\text { \%of } \\
\text { total }\end{array}$ & & \\
\hline$\leq 50$ & 1 & 2 & 6 & 12 & 2 & 4 & 7 & 14 & 3 & 2 & 13 & 12 & 14 & 14 \\
\hline $\begin{array}{l}\geq 50- \\
100\end{array}$ & 15 & 30 & 6 & 12 & 18 & 36 & 5 & 10 & 33 & 49 & 11 & 10 & 59 & 59 \\
\hline $\begin{array}{l}\geq 100- \\
150\end{array}$ & 22 & 44 & 0 & 0 & 15 & 30 & 3 & 6 & 37 & 32 & 3 & 6 & 37 & 37 \\
\hline total & 38 & 76 & 12 & 24 & 35 & 70 & 15 & 30 & 73 & 73 & 27 & 27 & 100 & 100 \\
\hline & \multicolumn{4}{|c|}{$\chi^{2}=18.1, P<0.0001$} & \multicolumn{4}{|c|}{$\chi^{2}=12.1, P<0.001$} & \multicolumn{4}{|c|}{$\chi^{2}=62.8, P<0.0001$} & & \\
\hline
\end{tabular}

Correlation showed: $r=0.9 ; P<0.001$ and $r=0.7, P<0.001$ in Group I and Group II respectively

Accordingly, correlation matrix analysis was used in all patients to find that the significant predictor for overall response were risk stratification; cervical nodal status and the mean ablative dose (Figure 2). However, multiple regression analysis revealed that the only predictor for response was the mean ablative dose.

\section{Discussion}

The current study revealed no significant associations between overall response in both groups and the different studied parameters except for the mean dose of RAI-131 $[r=0.9 ; P<0.001$ and $r=0.7, P<0.001$ in group I and II respectively]. It has been found that ablation depends on risk stratification; cervical nodal status and the mean RAI-131 ablative dose, while regression proved that the only predictor for response is the mean RAI-131 ablative dose. 
Rawson et al in $1951^{[12]}$, were the first to describe thyroid stunning as a temporal reduction in the cell's ability to concentrate iodine after exposure to relatively low radioactive iodine-131 for diagnostic images $(2-10 \mathrm{mCi})$, but did not kill the cell. Its significance was attributed to suppression the efficacy of radioactive 131 I ablative dose ${ }^{[13]}$.

It had been reported that administration of $2-5 \mathrm{mCi}$ of diagnostic radioactive iodine 131 (RI131) deliver absorbed doses of 4-38 and 10-58Gy to thyroid remnants ${ }^{[14,15]}$. Medvedec 200516 added that absorbed doses $>4$ Gy might result in thyroid stunning. However, Lundh et al ${ }^{[17,18]}$ showed that absorbed doses of $>0.15$ Gy produced a statistically significant reduction $(20 \%)$ in iodide transport 3 days after the end of irradiation. They added that 131I irradiation likely inhibited iodide transport independently of its action on cell cycle control mechanisms. This notion is further emphasized by the fact that thyroid stunning can readily be induced by $131 \mathrm{I}$ in growth-arrested G0 cells ${ }^{[17,18]}$.

In addition to the above, previous studies revealed an early increase in iodide transport/uptake after irradiation ${ }^{[19,20]}$. Meller et al. reported increased iodide uptake in 2 thyroid cell lines at various stages of differentiation up to $72 \mathrm{~h}$ after external irradiation ${ }^{[19]}$. Similarly Postgard et al ${ }^{[20]}$; reported an increase in iodide transport at times of less than $48 \mathrm{~h}$ after $131 \mathrm{I}$ irradiation of primary cultured pig thyrocytes, and if they were delayed in iodine administration, stunning was observed. These findings indicate that the time elapsed between diagnostic administration and therapeutic administration of 131I is crucial when the stunning phenomenon is being studied.

However, in 1994, Park ${ }^{[5]}$ and his associates showed that amounts of 131I larger than $2 \mathrm{mCi}$ have a sufficiently harmful effect on thyroid tissues to interfere with subsequent uptake of therapeutic amounts of 131I on the post ablation whole body scan for detection of any thyroid remnants or tumor foci. This had been noted at $3 \mathrm{mCi}$ dose, and becoming progressively greater with larger doses. This was attributed by shorter interval between administration of the ablation dose and postablation scanning, which leads to higher soft-tissue background, as a $24-48$ hour interval between ablation administration and postablation scanning. That is why it had been recommended to make the interval between the administration of the ablative dose and time of post ablative scanning 72 hours as in Cholewinski et al ${ }^{[21]}$ study.

Meanwhile; some authors argued that diagnostic scanning does not compromise I-131 therapy because the decreased uptake that has been attributed to temporary stunning is actually due to radiation damage that will ultimately result in cell death. If this "kill rather than stun" theory is true then thyroid stunning is likely to enhance I-131 cancer therapy because a Dx-WBS study would in fact be the first step in ablating cells that concentrate RAI-131 ${ }^{[13]}$.

Since the current study shortened the time elapsed between the diagnostic and therapeutic doses as much as possible, no statistical difference between both groups was noted in response. The overall response was almost identical [ $76 \%$ vs. $70 \%$; $P>0.05]$ indicating the possibility of avoiding stunning. Similar findings had been reported by Morris et al, 2011 and $2003^{[8,9]}$.

Fatourechi et al ${ }^{[22]}$, compared diagnostic $1-3 \mathrm{mCi}(37-111 \mathrm{MBq})$ of RAI 131 and post-therapy scans in a study designed to assess stunning. The authors did not specify when therapy was administered, but post-treatment scans were obtained after 3-5 days. They found reduced uptake in only $4 \%$ (5 of 117) of post- treatment scans to be hardly attributed to a stunning effect.

On the contrary, Bajen et al ${ }^{[23]}$ actually showed higher ablation success rates $(61.6 \%$ vs. $36.9 \%)$ in patients with stunning than in patients with no stunning. Therefore, the authors concluded that a therapeutic effect, rather than stunning, occurred with a diagnostic dose of $185 \mathrm{MBq}(5 \mathrm{mCi})$ i. e. adjuvant therapy. However, the time from diagnostic scanning to ablation was long in that study, namely an average of 7.9 weeks (range, 1-16 weeks), which raises the question as to whether stunning actually occurred or was there simply a decrease in tissue remnant. This was supported by Dam et al ${ }^{[24]}$ divided, in a retrospective study, their patients into no stunning and stunning groups and they found insignificant higher ablation success rates in stunning group. However, they concluded that stunning does not affect patient outcome. 
Karam et al retrospectively reported that success of RAI-131 ablation in 389 patients was mainly due to the size of the therapeutic dose ${ }^{[25]}$. Zaman et al ${ }^{[26]}$ confirmed that a single administration of about $30 \mathrm{mCi}$ failed to fully ablate the remnant $(46 \%)$ compared to $77-100 \mathrm{mCi}(27 \%, P<0.001) 26$ which is very similar to the current study. The current study in spite of being prospective still used ablative doses $<50 \mathrm{mCi}$ (in some patients) depending on those studies reporting complete ablation in thyroid bed in $80 \%$ of patients treated with $30-50 \mathrm{mCi}$ of $131 \mathrm{I}$, providing the surgeon had left small remnant of functioning tissue seen on a diagnostic WBIS using $2-3 \mathrm{mCi} 131 \mathrm{I}^{[27,28]}$.

Accordingly the current study agrees with the above findings regarding that the most influential and predicting factor in the final outcome [Response] is Radioactive Iodine-131 Ablative Dose. However, the current study showed in group II insignificant difference between odd ratio of patients treated with ablative dose between $>50-100$ and those treated above $>100-150 \mathrm{mCi}$, which could be explained by the fact that the amounts of 131I that deliver more than 300Gy do not result in a higher ablation rate. Lower success rates were found when large pretreatment scanning doses were used, regardless of the therapeutic dose of $131 \mathrm{I}$ and are attributed to thyroid stunning ${ }^{[26,29]}$.

In the current study, the ablative dose masked the impact of all other factors such as risk stratification and presence of cervical lymph nodes and even the histopathology that had been commented upon by Zaman et al ${ }^{[26]}$. This could be attributed by the fact that in our institute, the ablative dose was determined according to the other factors.

\section{Conclusion}

Thyroid stunning post-diagnostic iodine-131 dose could be avoided by taking the essential precautions when administering the ablative dose by giving it as soon as possible after reading the diagnostic image, and prolonging the interval between the ablative dose administration and time of imaging post therapy. If present, stunning will not affect the success of ablation dose. The most deterministic predictor for higher success ablation was the ablation dose.

\section{Declaration of interest}

The authors declare that they have no competing interest.

\section{References}

[1] Stokkel MP, Duchateau CS, Dragoiescu C: The value of FDG-PET in the follow-up of differentiated thyroid cancer: A review of the literature. Q J Nucl Med Mol Imaging. 2006; 50:78-87. PMid:16557207

[2] Mallick UK, Charalambous H: Current issues in the management of differentiated thyroid cancer. Nucl Med Commun. 2004; 25: 873-881. PMid:15319591 http://dx.doi.org/10.1097/00006231-200409000-00003

[3] Biersack HJ, Grünwald F: Thyroid Cancer (2 ${ }^{\text {nd }}$ ed.). New York, Springer; 2005. http://dx.doi.org/10.1007/3-540-27845-1

[4] Leger FA, Izembart M, Dagousset F, etal. Decreased uptake of therapeutic doses of iodine-131 after 185 MBq iodine-131 diagnostic imaging for thyroid remnants in differentiated thyroid carcinoma. Eur J Nucl Med. 1998; 25: 242-248. PMid:9580856 http://dx.doi.org/10.1007/s002590050223

[5] Park H-M, Perkins OW, Edmonson JW, Schnute RB, Manatunga A. Influence of diagnostic radioiodines on the uptake of ablative dose of iodine-131. Thyroid. 1994; 4: 49-54. http://dx.doi.org/10.1089/thy.1994.4.49

[6] DeKlerc JMH, DeKeizer B, Zelissen PMJ, Lips CMJ, Koppeschaar HPF. Fixed dosage of 131I for remnant ablation in patients with differentiated thyroid carcinoma without pre-ablative diagnostic 131I scintigraphy. Nucl Med Commun. 2000; 21 : 529-532. http://dx.doi.org/10.1097/00006231-200006000-00005

[7] Salvatori M, Perotti G, Rufini V, Maussier ML, Dottorini M. Are there disadvantages in administering 131I ablation therapy in patients with differentiated thyroid carcinoma without a preablative diagnostic 131I whole-body scan? Clin Endocrinol (Oxf). 2004; 61: 704-710. PMid:15579184 http://dx.doi.org/10.1111/j.1365-2265.2004.02153.x

[8] Morris LF, Waxman AD, Braunstein GD. The nonimpact of thyroid stunning: remnant ablation rates in I-131-scanned and nonscanned individuals. J Clin Endocrinol Metab. 2001; 86(8): 3507-3511. PMid:11502771

http://dx.doi.org/10.1210/jc.86.8.3507 
[9] Morris LF, Waxman AD, Braustein GD. Thyroid stunning. Thyroid. 2003; 13(4): 333-340. PMid:12804101 http://dx.doi.org/10.1089/105072503321669802

[10] Management guidelines for patients with thyroid nodules and differentiated thyroid cancer. The American Thyroid Association Guidelines Taskforce. Thyroid 2006; 16(2): 1-33. PMid:16487007

[11] Cooper DS, Doherty GM, Haugen BR, et al, Revised American Thyroid Association management guidelines for patients with thyroid nodules and differentiated thyroid cancer. Thyroid. 2009; 19(11): 1167-1214. PMid:19860577 http://dx.doi.org/10.1089/thy.2009.0110

[12] Rawson RW, Rall JE, Peacock W. Limitations and indications in the treatment of cancer of the thyroid with radioactive iodine. The Journal of Clinical Endocrinology \& Metabolism. 1951; 11(10): 1128-1142. http://dx.doi.org/10.1210/jcem-11-10-1128

[13] Robert J, Ernest L Mazzaferri Essentials of thyroid cancer management Ed: Robert J and Ernest L Mazzaferri Ch. 2-3 Thyroid Stunning. 2005:55-59; SPRINGER-Verlag.

[14] Jeevanram RK, Shah DH, Sharma SM, Ganatra RD. Influence of initial large dose on subsequent uptake of therapeutic radioiodine in thyroid cancer patients. Nucl Med Biol. 1986; 13: 277-279.

[15] Lassmann M, Luster M, Hänscheid H, Reiners C. Impact of 131I diagnostic activities on the biokinetics of thyroid remnants. J Nucl Med. 2004; 45: 619-625. PMid:15073258

[16] Medvedec M. Thyroid stunning in vivo and in vitro. Nucl Med Commun. 2005; 26(8): 731-5. PMid:16000993 http://dx.doi.org/10.1097/01.mnm.0000169380.92270.73

[17] Lundh C, Nordén MM, Nilsson M, Forssell-Aronsson E. Reduced iodide transport (stunning) and DNA synthesis in thyrocytes exposed to low absorbed doses from 131I in vitro. J Nucl Med. 2007; 48(3): 481-6. PMid:17332627

[18] Lundh C, Lindencrona U, Postgård P, Carlsson T, Nilsson M, Forssell-Aronsson E. Radiation-induced thyroid stunning: differential effects of (123)I, (131)I, (99m)Tc, and (211)At on iodide transport and NIS mRNA expression in cultured thyroid cells. J Nucl Med. 2009; 50(7): 1161-7. PMid:19525464 http://dx.doi.org/10.2967/jnumed.108.061150

[19] Meller B, et al, Decreased radioiodine uptake of FRTL-5 cells after (131) I incubation in vitro: molecular biological investigations indicate a cell cycle-dependent pathway. Eur J Nucl Med Mol Imaging. 2008; 35(6): 1204-12. PMid:18228019 http://dx.doi.org/10.1007/s00259-007-0666-0

[20] Postgård P, Himmelman J, Lindencrona L, et al. Stunning of iodide transport by (131) I irradiation on cultured thyroid epithelial cells. J Nucl Med 2002; 43:828-834. PMid:12050329

[21] Cholewinski SP, Yoo KS, Klieger PS, O'Mara RE. Absence of thyroid stunning after diagnostic whole-body scanning with 185 MBq 131I. J Nucl Med. 2000; 41:1198-1202. PMid:10914909

[22] Fatourechi V, Hay ID, Mullan BP, et al. Are posttherapy radioiodine scans informative and do they influence subsequent therapy of patients with differentiated thyroid cancer? Thyroid. 2000; 10: 573-577. PMid:10958309 http://dx.doi.org/10.1089/thy.2000.10.573

[23] Bajen MT, Mane S, Munoz A, Garcia JR.Effect of diagnostic dose of $185 \mathrm{MBq} 131 \mathrm{I}$ on postsurgical thyroid remnants. J Nucl Med 2000; 41: 2038-2042. PMid:11138690

[24] Dam HQ, Kim SM, Lin HC, Intenzo CM. 131I therapeutic efficacy is not influenced by stunning after diagnostic whole-body scanning. Radiology. 2004; 232:527-533. PMid:15286323 http://dx.doi.org/10.1148/radiol.2322030528

[25] Karam M, Gianoukas A, Feustel PJ, et al. Influence of diagnostic and therapeutic doses on thyroid remnant ablation rates. Nucl Med Commun. 2003; 24: 489-495. PMid:12717064 http://dx.doi.org/10.1097/00006231-200305000-00002

[26] Zaman M, Toor R, Kamal S, Maqbool M, Habib S, Niaz K A Randomized clinical Trial Comparing 50mCi and 100mCi of Iodine-131 for ablation of Differentiated Thyroid Cancers. JPMA. 2006; $56: 353$.

[27] Maxson HR 3rd, Englaro EE, Thomas SR, Hertzberg VS, Thinnefeld JD, Chen LS. Radioiodine-131 therapy for well differentiated thyroid cancer- a quantitative radiation dosimetric approach outcome and validation in 85 patients. J Nucl Med. 1992; 33: 1132-6.

[28] Mazzaferri EL, Kloos RT. Current approaches to primary therapy for papillary and follicular thyroid cancer. J Clin Endocrinol Metab. 2001; 86:1447-1463. http://dx.doi.org/10.1210/jc.86.4.1447

[29] Bal CS, Kumar A, Pant GS. Radioiodine dose for remnant ablation in differentiated thyroid carcinoma: a randomized clinical trial in 509 patients. J Clin Endocrinol Metab. 2004; 89(4):1666-73. PMid:15070929 http://dx.doi.org/10.1210/jc.2003-031152 